\title{
Quality Control of Silvicultural Operations in Eucalyptus Plantation
}

\author{
Adenise Aparecida Ulchak ${ }^{1}$ (D) 0000-0001-9440-2454 \\ Ricardo Anselmo Malinovski ${ }^{1}$ (D) 0000-0003-2421-6132 \\ Nilton José Sousa ${ }^{1}$ (D) 0000-0003-3551-2527 \\ Renato Cesar Gonçalves Robert ${ }^{1}$ (D) 0000-0003-0598-5112
}

\begin{abstract}
Market demands lead companies to improve their processes by implementing quality management. Quality management is inserted to support decision-making in quality control assessments to allow variability reduction, achieving homogeneity when added to the standardization of methodologies, which is the main characteristic desired by the industry. Our study seek to analyze if quality control of silvicultural operations in a forest-based company showed an increased compliance index between 2012 and 2016; and to analyze the efficiency of quality control evaluation through comparative analyzes with the methodology proposed by Shewhart for the most outlier operation. The evaluations have shown that quality assessments did not present a regular evolutionary pattern in the period evaluated. The herbicide application activity was the most outlier operation, since it did not show a trend for constant improvement.
\end{abstract}

Keywords: continuous improvement, quality management, forest plantations.

\section{INTRODUCTION AND OBJECTIVES}

The constant evolution of the consumer market and its demands for products with increasingly high quality have triggered a search for continuous improvement and enhancement in the productive chains processes of all sectors. Forest market is not an exception, since the sector plays an essential role in Brazilian economy. It has incorporated quality control practices in its activities of operations, from the first sector until the end of the chain.

Benefits such as increased competitiveness, maximized forest productivity, uniformity and compliance in the quality of operations, and, consequently, greater profitability, as well as certifications are factors that lead to quality management, assisting in strategic and most tactical decision-making processes (Vettorazzi \& Ferraz, 2000).

According to Milan \& Fernandes (2002), "quality is the reduction of variability. The lower the variability the better the reliability and acceptance of the product or service". The information produced by the quality evaluations allow to identify failures, requiring faster corrective actions by reducing productivity loss.
Investment in quality must be well-founded; major challenges are assumed with a long-term vision and changing the managerial posture is also important. Achieving the desired quality means involving people in the production process, motivating them to contribute to the improvement of this process. Thus, the quality tools are elements that facilitate the implementation of the participatory quality system, aiming at continuous process improvement (Trindade et al., 2007).

The use of suitable quality tools plays a key role in a quality control assessment. According to Giron et al. (2013), the control charts currently compose one of the most widely used quality methodologies in the control of processes and products based on statistical analyses. The process is constantly monitored, through centralization (verified through the average) and dispersion (estimated by standard deviation or amplitude). Control charts are divided into two categories: variables and attributes. Variables are based on continuous distributions, pointing to data that can be measured or that undergo continuous variations. The control charts by attributes are based on discrete distributions, of dichotomous nature, in which the data can only be counted or classified (Christino et al., 2010).

\footnotetext{
${ }^{1}$ Universidade Federal do Paraná (UFPR), Curitiba, PR, Brasil
} 
The usual standardized process definition is enabling companies to reach higher performance and quality in their activities. Following the standard means that the activity will be always performed using a predefined optimal way, regardless the person involved (Schafermeyer et al., 2010). Therefore, activity standardization becomes even more important when it is developed by several people and outsourced companies, because these factors hinder the homogeneity of operations, making quality control vital to the production process, since the failure in the beginning of the process will entail a higher cost at the end of the chain.

In this context, our study sought was to analyze if the quality control of silvicultural operations in a forest-based company showed an increased compliance index between 2012 and 2016; and to analyze the efficiency of the quality control evaluation through comparative analysis with the methodology proposed by Shewhart for the most outlier operation.

\section{MATERIALS AND METHODS}

Our study was developed in a company that uses eucalyptus trees as raw material to wood panels. It is located in the interior of the Brazilian state of São Paulo, in the macroregion of Sorocaba, under the influence of the Cfa climate, according to the Köppen classification, with a $20.2{ }^{\circ} \mathrm{C}$ average temperature, and an $1,236 \mathrm{~mm}$ average annual rainfall. The area has soils predominantly classified as sandy clay loam, and the relief is mild, slightly undular to flat.

\subsection{Data collection}

The silvicultural process was analyzed, specifically: (i) seedlings expedition; (ii) soil preparation; (iii) herbicide application; (iv) planting; and (v) mechanized fertilization. The sampled data was obtained from a database of the quality control sector of the period between 2012 and 2016.

\subsection{Evaluation of operations}

The evaluations were conducted following the technical procedures of the company, resulting in a general grade for the operation, ranging from 0 to $100 \%$, since the objective stipulated by the company was $90 \%$ of conformity. With the data collected, graphs were generated for analysis and control, which are the main management tool for operations.

The quality assessment occurs in three levels. In the first phase, the outsourced company (OC) performs daily evaluation according to a technical procedure, all failures identified are corrected at the moment. In the second phase, the OC is audited by the contractor's own team and the evaluation follows the same methodology of the first phase. It occurs randomly, and without a pre-defined time interval. Finally, in the third phase, the management team analyzes the information collected in the two previous stages, and suggests actions for improvement.

The activities evaluated were:

- Seedlings quality: the evaluation occurred at the time of expedition, after the boxing of the seedlings in the nursery. The parameters evaluated were: height of the seedlings, root collar diameter, non-rustified seedlings, broken and/or bifurcated seedlings, phytosanitary, active roots and substrate inconsistency.

- Planting: the operation occurred in two ways: the manually and mechanically planting hole. In the manual plantation system, the operators performed the "irrigation ditch", which is the process of demarcating an area of approximately $30 \mathrm{~cm} \times 30 \mathrm{~cm}$ and $10 \mathrm{~cm}$ deep with the foot, planting the seeds in the center. The irrigation ditch sought to keep the hydrogel water contained near the seedling. In the mechanical plantation system, the "irrigation ditch" was demarcated by the subsoil at the moment of soil preparation. The quality of this activity was determined through the analysis of the size and depth of the irrigation ditch and the analysis of the seedlings planted: number of seedlings tortuous planted, drowned (root collar covered by soil) and lack of firmness. The parameters evaluated in the manual plantation system were (i) size and depth of the irrigation ditch, (ii) firmness of the seedling, (iii) drowning, (iv) tortuosity of planting, and (v) broken seedling. In the mechanical plantation system, the distance between plants was evaluated instead of the size and depth of the irrigation ditch. The analysis of the seedlings planted followed the same parameters of the planting hole system.

- Application of herbicides: the application occurred in two ways: with protected bar (application in the space between rows) and with long bar without protection (application in total area). The evaluation considered the amount (dosage/ha) of the product used for spraying, and if such dosage was within the recommended dosage for the area. Several parameters were collected for the flow rate calculation and uniformity: (i) the time of the tractor to cover 50 meters; (ii) the size of the implement (long unprotected bar or protected bar); (iii) distance between nozzles; (iv) nozzle height; (v) flow rate; and (vi) uniformity of application. 
- Soil preparation: the evaluation consisted of the sum of two evaluations: subsoiling and fertilization. The objective was to verify the subsoiling quality (size and angle of the furrow), the amount of fertilizer applied per hectare and its proper depth in the soil. The parameters evaluated were: (i) the time of the tractor to cover 50 meters; (ii) fertilizer dosage; (iii) furrow depths; (iv) fertilizer depths; and (v) furrow angle.

- Fertilization: the evaluation considered only the amount of fertilizer per hectare.

For each item evaluated by operation, an empirical weight was assigned by the evaluated company. These weights were adopted for the evaluations in our study, the standard values are found in Table 1.

To analyze the quality grade, we used variable control charts and graphs based on the methodology proposed by Shewhart using the concept of statistical process control (SPC). The conventions used in the graphs were described as lower control limit (LCL), upper control limit (UCL) and centerline (C). Limits resulted from statistical analysis and were determined according to the process variability, that is, the centerline was defined by the average of the process and upper and lower control limits were estimated based on the standard deviation of the variables (for UCL, average plus three times the standard deviation, and for LCL, average minus three times the deviation). Zero was considered as the minimum value of the lower limit in cases in which they were negative (Trindade et al., 2007).

Table 1. Weight of each parameter evaluated in the operations.

\begin{tabular}{|c|c|c|}
\hline Evaluated item & Operation & Weight/item (\%) \\
\hline Height & Seedlings & 10 \\
\hline Root collar diameter & Seedlings & 15 \\
\hline Rusticity & Seedlings & 20 \\
\hline Bifurcation & Seedlings & 5 \\
\hline Leaf health & Seedlings & 10 \\
\hline Active roots & Seedlings & 20 \\
\hline Substrate consistency & Seedlings & 20 \\
\hline Size and depth of the irrigation ditch or distance between plants & Planting & 20 \\
\hline Firmness of the seedling & Planting & 20 \\
\hline Depth of seedling (drowning) & Planting & 20 \\
\hline Alignment of substrate (tortuosity) & Planting & 20 \\
\hline Seedling quality (broken) & Planting & 20 \\
\hline Uniformity & Herbicide & 50 \\
\hline Flow rate & Herbicide & 50 \\
\hline Fertilizer dosage -1 & Soil preparation & 20 \\
\hline Fertilizer dosage - 2 & Soil preparation & 20 \\
\hline Furrow depth & Soil preparation & 20 \\
\hline Fertilizer depth -1 & Soil preparation & 20 \\
\hline Fertilizer depth -2 & Soil preparation & 20 \\
\hline Fertilizer dosage & Fertilization & 100 \\
\hline
\end{tabular}

\section{RESULTS}

Table 2 shows the statistical analysis of the samples separated by operation between 2012 and 2016 .

We considered the average compliance index of the operations evaluated (seedlings, planting, herbicide, soil preparation, and fertilization) per year to obtain a general average index of activities, as shown in Figure 1. We noticed an increase in the general compliance index up to 2015, and stabilization between 2015 and 2016. The index is currently within the range acceptable by the company, that is, above $90 \%$ of conformity. 
Table 2. Results from the sampling in the evaluated operations.

\begin{tabular}{lccccc}
\multicolumn{1}{r}{ Parameter } & \multicolumn{5}{c}{ Evaluated operations } \\
\cline { 2 - 6 } & Seedlings & Planting & Herbicide & Soil preparation & Fertilization \\
\hline Sample average & $94 \%$ & $93 \%$ & $77 \%$ & $86 \%$ & $87 \%$ \\
\hline Standard deviation & $4 \%$ & $4 \%$ & $21 \%$ & $16 \%$ & $26 \%$ \\
\hline Coefficient of variation & $4 \%$ & $4 \%$ & $27 \%$ & $18 \%$ & $30 \%$ \\
\hline Standard error & $1 \%$ & $1 \%$ & $9 \%$ & $3 \%$ & $83-91 \%$ \\
\hline Confidence interval & $93-96 \%$ & $92-94 \%$ & $68-86 \%$ & $83-89 \%$ & \\
\hline
\end{tabular}

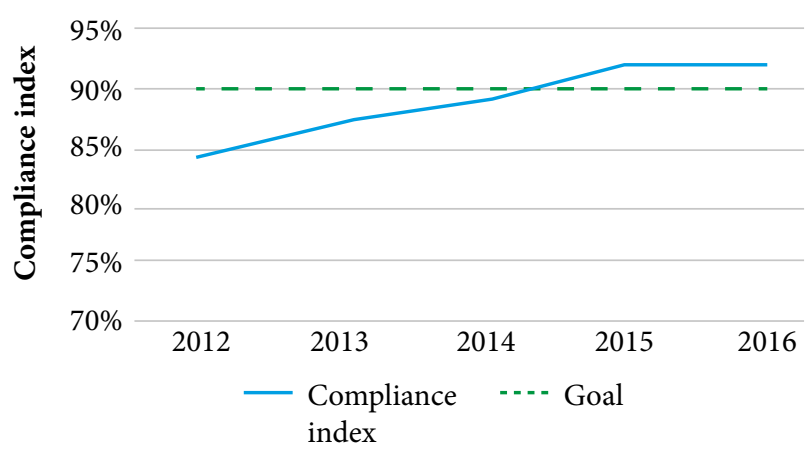

Figure 1. Evolution of the average compliance index of silviculture operations (2012-2016).

However, greater variations were observed in the activity compliance index when each operation were analyzed separately (Figure 2). Although the data of seedling and planting quality control showed variations without upward trend from the outset, they were above the pre-established $90 \%$ compliance standard for the entire period evaluated. Soil preparation and fertilization showed increased performance in the analyzed period. Nevertheless, they were below the average required by the company (90\%) at the beginning of the analyzed period (2012); both are above the minimum required in 2015, and the continuous improvement in the process was noted by the ascendancy of the curve. Regarding the application of herbicide, we observed abrupt changes in the pattern, the activity started with the target compliance in 2013, after that, in 2014, there was a 20\% decrease in the compliance index, in 2015 it was above de minimum, decreasing again in 2016.

In some cases, the average value of the data series does not represent the real situation as a result of the grade amplitude.
This is this reason why a percentage of sample conformity of all evaluations accomplished for each activity and year was calculated. The values are shown in Figure 3. The herbicide activity showed a 90\% average compliance index in 2013 when the information in both graphs were compared; however, $50 \%$ of the evaluations were below de goal. The goal is to have $100 \%$ of the samples above $90 \%$ compliance index, as showed in the herbicide activity in 2015 and in seedlings and soil preparation, in 2016. Following the same tendency as in the Figure 2, the operation of herbicide application was the most outlier operation because most samples were below the goal, without a trend of constant improvement due to the decreased percentage of sample conformity between 2013 and 2014, in opposition the established hypothesis between 2015 and 2016. Although the other activities were below the goal, they showed an increasing trend.

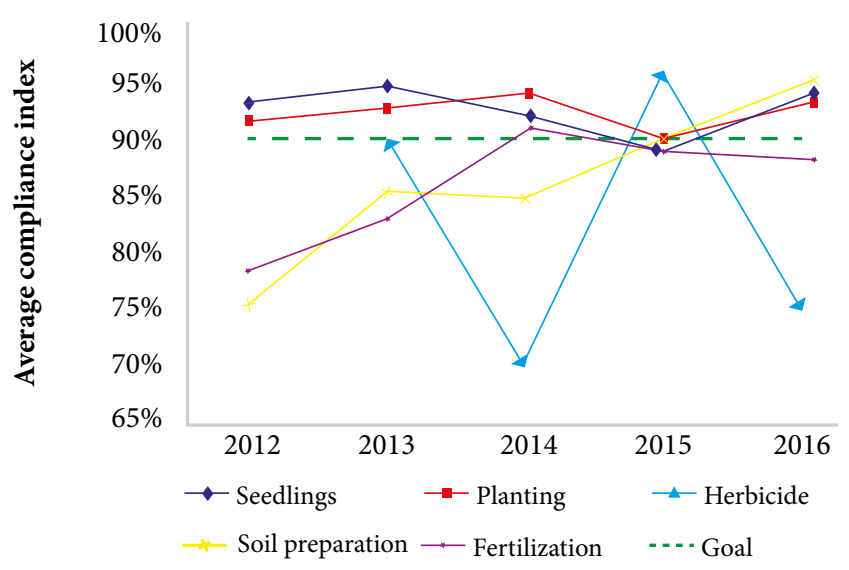

Figure 2. Quality control evolution of silvicultural operations. 


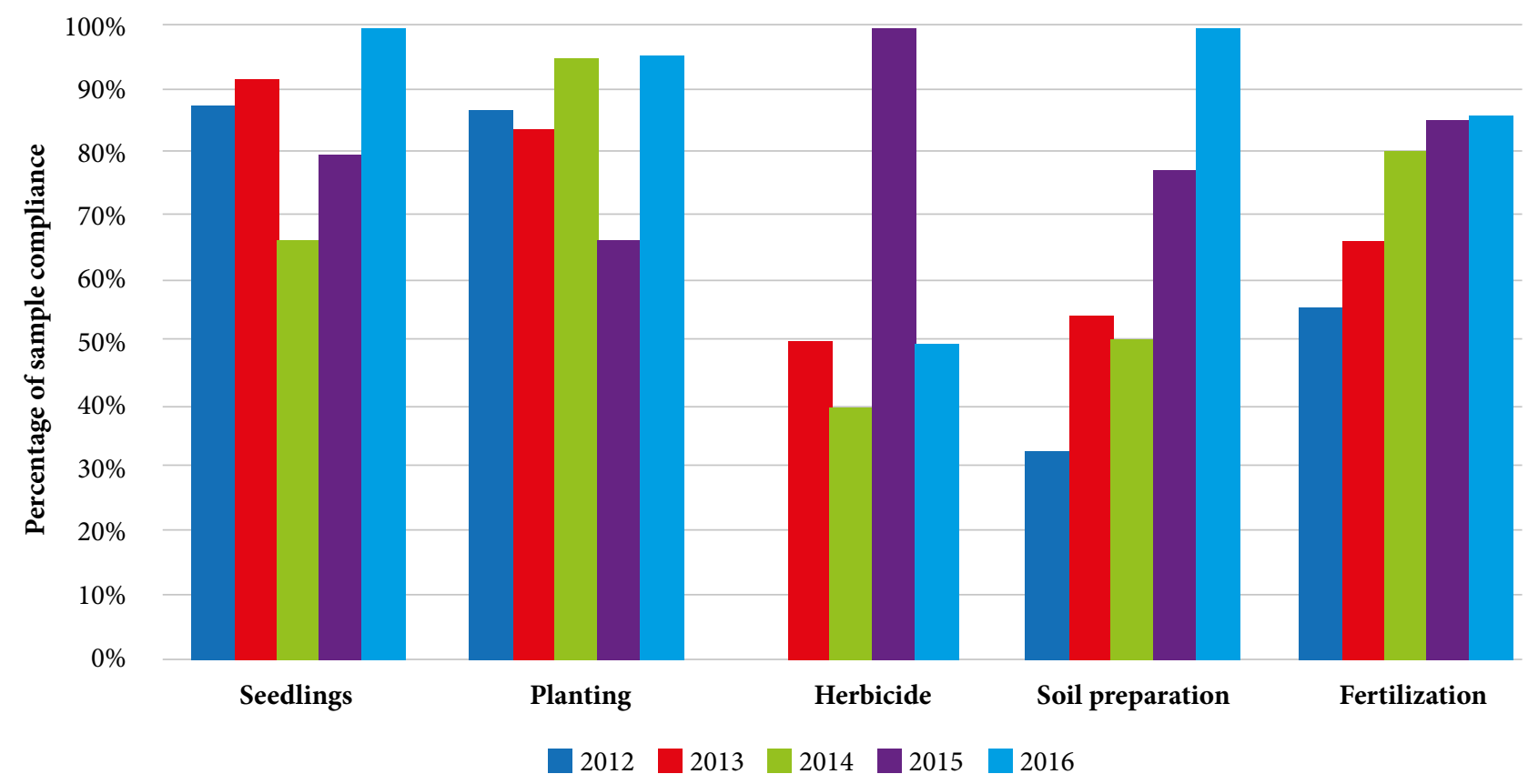

Figure 3. Percentage of sample compliance for seedlings, planting, herbicide, soil preparation and fertilization, between 2012 and 2016.

The indicators that determined the quality grade of herbicide operations were flow rate and uniformity, i.e. if the equipment was calibrated for the recommended dosage and if the herbicide was evenly distributed. As the flow rate is calculated according to each situation, there is no standard fixed value for the flow rate. This is the reason why the flow rate applied to each sample was evaluated using control charts, as shown in Figure 4. Note that the samples differed significantly. In this case, values close to zero represented better results, negative values meant that the dosage was lower than the recommended, consequently values above zero represented a higher dosage than recommended.

Uniformity is determined by the coefficient of variation $(\mathrm{CV})$, in which the ideal values are close to zero. Since smaller values indicate greater uniformity, the higher the coefficient of variation, the greater the irregularity of the operation. According to the control chart, as shown in Figure 5, a 25\% coefficient of variation was accepted as the centerline, that is, 1.7 times higher than the maximum recommended in the literature. The maximum limit established by the company was $10 \%$, that is, $71 \%$ of the process samples were out of operational control.

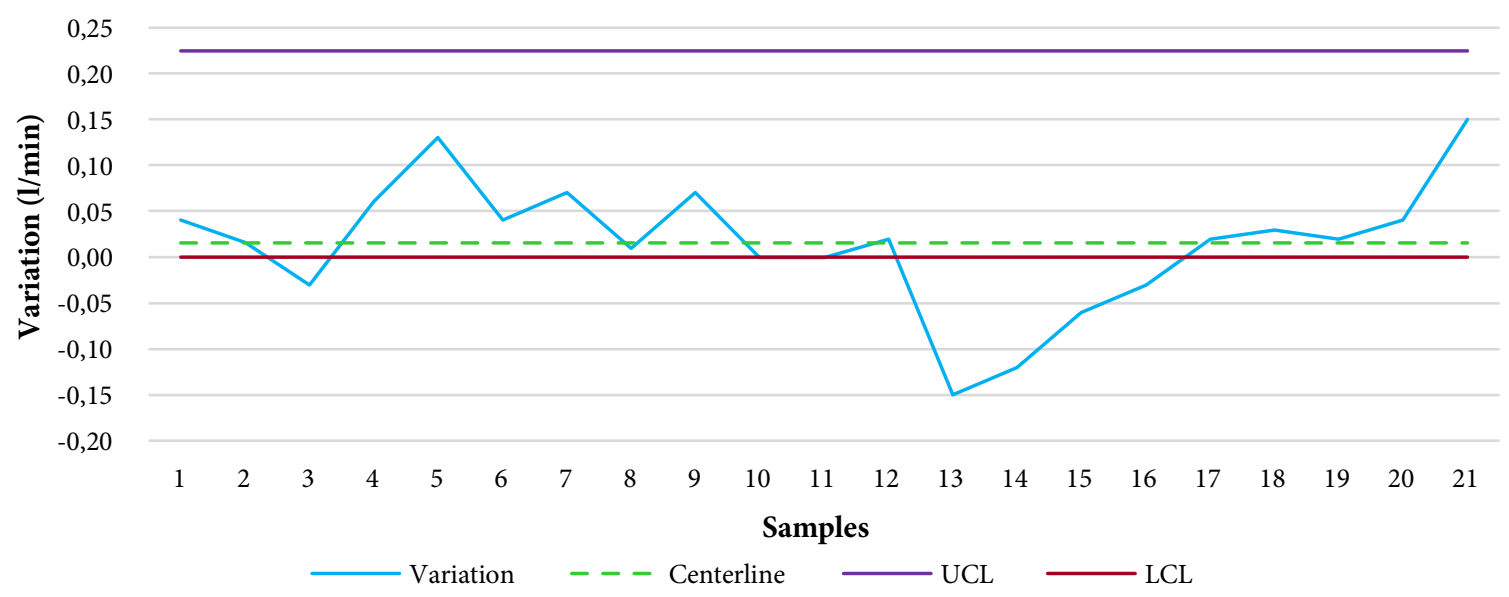

UCL: upper control limit; LCL: lower control limit.

Figure 4. Quality indicators - Herbicide: Flow rate variation. 


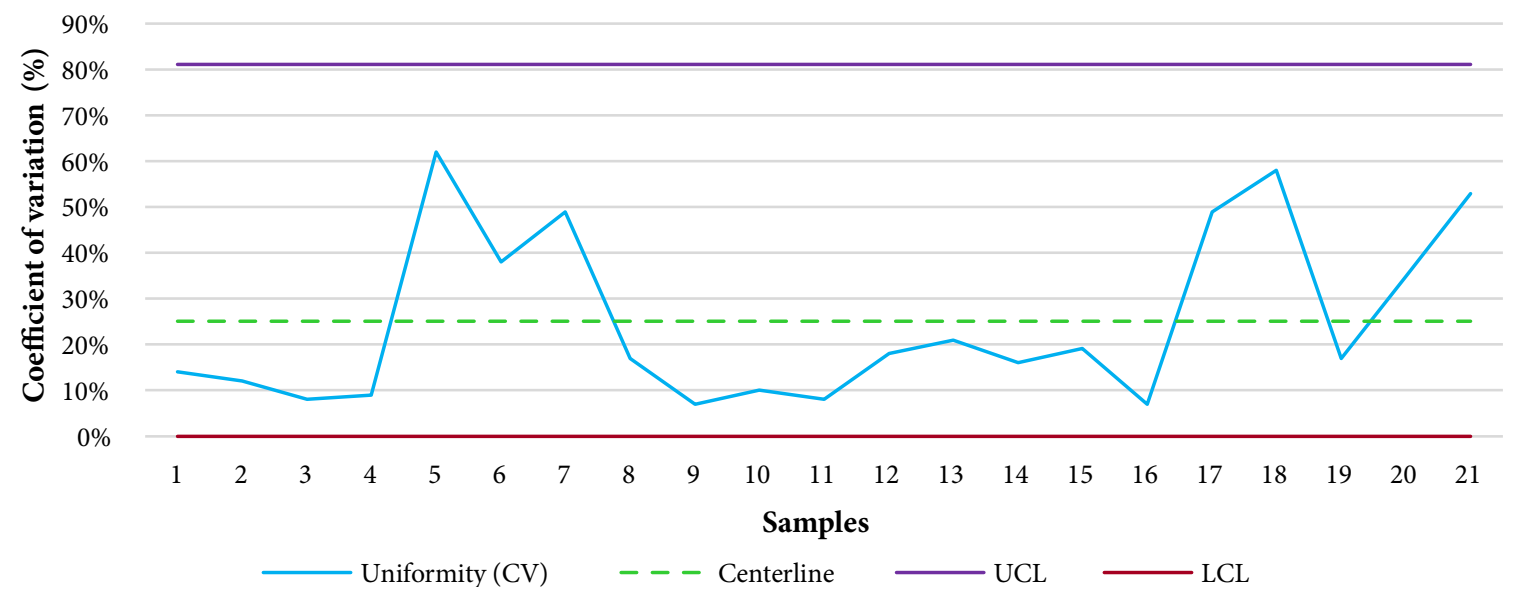

CV: coefficient of variation; UCL: upper control limit; LCL: lower control limit.

Figure 5. Quality indicators - Herbicide: Uniformity.

\section{DISCUSSION}

Milan \& Fernandes (2002) affirm that the greater the operation control, the lower the process variability, obtaining results closer to the specifications. The data obtained in our study contradict this statement. In the evaluations, we verified that the expected operation quality did not occur for all activities evaluated over time. This divergence between results may be related to factors that were not controlled in the performed samplings such as the lack of skilled workforce in the execution of the evaluated activities. Another possibility is the sample intensity of our study, which may have been insufficient or even the methodology adopted, which could not have had the intensity of evaluation that the activities required.

\subsection{Seedlings}

Regarding the quality evaluation of seedlings, according to Silva et al. (2012), the morphological parameters are the most used in determining the quality standard. The standard evaluation adopted by the company is satisfactory and includes the items suggested by the cited author: the height of the seedling, root collar diameter, total dry matter weight, aerial part dry matter weight, root dry matter weight, and Dickson quality index (DQI), among others. Based on these parameters, we could verify that the compliance index was above the goal and increasing over time between 2012 and 2013 ; and the quality standard decreased (95\% to $92 \%$ ) in 2014 , justified by the change in the minimum diameter of seedlings. In 2016, the compliance index increased again, reaching $96 \%$, and the quality index for this activity was uniform with $100 \%$ of samples within compliance.

\subsection{Planting}

The planting quality is influenced by the seedlings quality and the area preparation (subsoiling, basal fertilization and weed control). According to Wilcken et al. (2008), planting quality must have attention at the planting time, since the root collar should always remain at ground level, to not expose de roots or let the stem under the ground.

The planting was performed manually, thus suffering a lot of variation due to the presence of more than one person in the operation, showing the need of a workforce trained according to the technical specifications to achieve homogeneity. The activity showed compliance throughout the analyzed period, as shown in Figure 2.

One of the parameters that mostly reduces the quality grade of the activity is the indicator "size and depth" of the irrigation ditch, since the hole is made with the operator's own foot, without the aid of any equipment. Moreover, all the evaluated items had the same weight, so it would be ideal to evaluate each one of these indicators and its correlation with the good development of the forest and its productivity in order to enable factors attribution with greater precision.

\subsection{Herbicide}

Firstly, reaching the goal is necessary to achieve success in the herbicide application, and knowing the deposition characteristics regulated by the equipment, product and application form is necessary to achieve adequate coverage of the area by the product (Ferreira et al., 2009). The author also mentions that, at each distance between application ranges or between nozzles in the bar of a sprayer, there are varied 
uniformity overlapping patterns, which is a component for the analysis of the coverage variability. The most indicated tool in this situation is the CV. According to Fernandes et al. (2007), values above $15 \%$ of CV indicate worn tips, different tips in the bar, varied spacing between the nozzles and even poor quality of the spray tips. These factors may have affected the uniformity of the activity.

The outcome of herbicide evaluation was not appropriate yet and the grades showed variation. By using the control charts, we verified that the processes are not under control due to points poorly distributed around the centerline, points outside the control limits, besides ascending and descending periods generating high variability in the process, thus admitting higher limits of control, proving that the process does not follow a standard. We could identify failures in the operation using the charts; however, we could not identify the causes.

Moreover, the current evaluation analyzed only the machinery calibration, without any connection with the efficiency of the control, neither evaluated the time of application, which are the most important factors for the operational effectiveness. Bastiani et al. (2000) showed in an experiment that control efficiency in advanced plants was not achieved by comparing the application of an herbicide in early stage and late stage weeds. Therefore, the planning of the activities must be up to date, in order not to compromise the quality of the operation besides the proper functioning of the equipment.

Other influence items are suggested to be included in the evaluation of herbicide application such as: water quality $(\mathrm{pH})$ and weed control efficiency. Mescalchin et al. (2013) suggest indicators such as droplet density and percentage of droplet coverage through hydrosensitive cards, in this study the evaluation was performed through the Herbicat ${ }^{\circ}$ calibration case and distribution table.

\subsection{Soil preparation}

The quality evaluation of this activity was performed with a graduated iron rod to verify soil preparation depth. A soil portion was carefully removed to measure the shape of the groove with the aid of a hoe. There are similarities between this methodology and he one used by Gonçalves et al. (2016), which suggest that subsoil quality assessments should consider the depth, groove shape and distances between rows, determining the depth using a graduated iron rod and a template.

However, the methodology used in this study differs from the methodology recommended by Gava (2003), which indicates the use of a penetrograph to determinate soil resistance in points distributed in the preparation groove. In this technique, the equipment generates graphs as a result of the change in soil resistance. These graphs can be compared with the technical procedure recommended for the operation.

The data indicated that compliance index were lower than the $90 \%$ standard adopted by the company in 2012, 2013 and 2014. In that period, the percentage of sample compliance was $33 \%, 54 \%$ and 50\%, respectively. In 2015 and 2016, the index increased, reaching $98 \%$, and $100 \%$ of samples within compliance in 2016. This change in the percentages of compliance may be associated with possible errors in the methodology adopted.

We observed a decrease (2014) and uniformity (2016) in the evaluations, as the methodological procedures were consolidated.

\subsection{Top fertilization}

The conformity of the assessments has improved over the years, increasingly becoming more consistent with the quality grade established. Fertilization is essential for forest plantations to reach adequate growth rates and productivity patterns (Pereira et al., 2012). Thus, quality control in fertilization is necessary, since quality fertilization in the correct period is important to a more even forest development and to avoid impairment in wood quality due to an irregular growth rate.

According to Wilcken et al. (2008), top fertilization seeks to provide the soil with nutrients with high soil mobility such as: nitrogen, potassium and boron. They should be located in a continuous fillet, in the case of mechanized application, $30 \mathrm{~cm}$ from the Eucalyptus seedlings.

Thus, we observed that the distance of localization of the fertilizer is important for the process. The distance was not in the evaluation methodology, which considered only the dosage/ha. Application distance should be another item incorporated in the evaluation, since it interferes in planting quality, then the quality grade could represent, in fact, the condition of the operation.

Bazani et al. (2014) compared dosing data with and without GPS controller to better understand the variability in the fertilizer distribution in each situation. They found that $82 \%$ of the data were within $10 \%$ variation with GPS controller and only $12.5 \%$ of the data were within $10 \%$ variation without the controller. This finding showed the benefit of the implementation of a fertilization system with GPS controller, with which it is possible to control the amount and flow of the fertilizer by the speed of the tractor, thus increasing the precision of the operation and making the recommended amount to the plants available. Another advantage is that the quality control seems to be performed 
integrally and no longer by sampling, eliminating sample errors and the need of a collection team. The company did not use this methodology.

The addition of indicators to be evaluated allow greater control and, consequently, a higher quality of the activity and the forest plantation. Thus, we could observe that the evaluation performed by the company can be complemented, in addition to the dosage, the distance between the fillet of fertilizer and the plant, the adoption of precision systems as well as the quality of the fertilizer used. Currently, the quality grade is based upon only one parameter (dosage/ ha) that is regulated by the tractor, that is, if the tractor is well regulated the grade will be $100 \%$. However, if the other factors that may affect the operation quality are not observed, the forest will not grow as expected and the quality control will not achieve its goal.

\section{CONCLUSIONS}

- Quality assessments did not present a regular evolutionary pattern in the period evaluated;

- Three evaluated activities (seedlings, herbicide and soil preparation) had uniform compliance index (100\% of samples) in one of the evaluation years;

- In most years, the evaluated activities had samples with a compliance index lower than the goal stipulated by the company ( $90 \%$ compliance);

- In the period of the evaluations, the seedling and planting activities had higher compliance index than the company stipulated;

- The herbicide application activity was the most outlier operation, the compliance index was lower than the goal stipulated by the company in 2014 and 2016, and it did not show a trend for constant improvement.

- The soil preparation activity showed a compliance index that increasingly evolves between 2012 and 2016, except for the year 2014, which was lower than 2013 , reaching uniformity in 2016 , with $100 \%$ of the samples above the index;

- The fertilization activity showed an increased compliance index between 2012 and 2015, with a decrease in 2016. The activity did not present $100 \%$ of the samples with compliance in any of the evaluated years.

\section{ACKNOWLEDGEMENTS}

The authors thank the forestry company and the quality control sector, for transferring the data for the study; and prof. dr. Ricardo Malinovski for his valuable guidance and support, and all those indirectly involved that contributed to the achievement of this article.

\section{SUBMISSION STATUS}

Received: 27 Aug. 2017

Accepted: 7 Jan. 2019

Associate editor: José Henrique Tertulino Rocha

0000-0002-7471-4191

\section{CORRESPONDENCE TO Adenise Aparecida Ulchak}

Universidade Federal do Paraná (UFPR), Av. Prefeito Lothário Meissner, 632, CEP 80210-170, Curitiba, PR, Brasil

e-mail: adenise.ulchak@gmail.com

\section{REFERENCES}

Bastiani MLR, Silva AA, Ferreira FA, Cardoso AA. Influência de chuva simulada após aplicação de herbicidas em pós-emergência, sobre o controle de plantas daninhas, em solo com dois níveis de umidade. Planta Daninha 2000; 18(1): 57-70. 10.1590/S010083582000000100006

Bazani JH, Gonçalves JLM, Rocha JHT, Melo EASC, Prieto MR. Nutrição fosfatada em plantações de eucalipto. Informações Agronômicas 2014; (148): 1-11.

Christino EM, Bonduelle GM, Iwakiri S. Aplicação de cartas de controle no processo de fabricação de pisos sólidos de Tauari (Couratari oblongifolia). Cerne 2010; 16(3): 299-304. 10.1590/ S0104-77602010000300006

Fernandes AP, Parreira RS, Ferreira MC, Romani GN. Caracterização do perfil de deposição e do diâmetro de gotas e otimização do espaçamento entre bicos na barra de pulverização. Engenharia Agrícola 2007; 27(3): 728-733. 10.1590/S0100-69162007000400016

Ferreira MC, Di Oliveira JRG, Dal Pietro IRPS. Distribuição da calda herbicida por pontas de pulverização agrícola utilizadas em áreas de reflorestamento com eucalipto. Engenharia Agrícola 2009; 29(2): 267-276. 10.1590/S0100-69162009000200010

Gava JL. Avaliação da qualidade do preparo do solo em áreas de eucalipto plantado no sistema de cultivo mínimo do solo. Boletim de Pesquisa Florestal 2003; (47): 55-68.

Giron E, Opazo MAU, Rocha WF Jr, Gimenes RMT. Aplicação do controle estatístico de processo em uma empresa do setor avícola. RAI: Revista de Administração e Inovação 2013; 10(4): 38-62. 10.5773/rai.v10i4.891

Gonçalves SB, Lopes ES, Fiedler NC, Cavalieri KMV, Stahl J, Drinko CHF. Efeito da profundidade de trabalho na qualidade da operação de subsolagem para implantação florestal. Árvore 2016; 40(1): 29-37. 10.1590/0100-67622016000100004 
Mescalchin E, Agabiti B, Bertoldi D, Larcher R, Gobber M, Guerra A et al. Checking the distribution quality of agrochemicals in the vineyard through the use of field monitoring. Acta Hortic 2013; 978: 237-243. 10.17660/ActaHortic.2013.978.27

Milan M, Fernandes RAT. Qualidade das operações de preparo de solo por controle estatístico de processo. Scientia Agricola 2002; 59(2): 261-266. 10.1590/S0103-90162002000200009

Pereira FCM, Yamauti MS, Alves PLCA. Interação entre manejo de plantas daninhas e adubação de Cobertura no crescimento inicial de Eucalyptus grandis $\times$ E. urophylla. Revista Árvore 2012; 36(5): 941-949. 10.1590/S0100-67622012000500016

Schafermeyer M, Grgecic D, Rosenkranz C. Factors influencing business process standardization: a multiple case study. In: $43 \mathrm{rd}$ Hawaii International Conference on System Sciences (HICSS); 2010; Honolulu. New York: IEEE; 2010. p. 1-10. 10.1109/HICSS.2010.207
Silva RBG, Simões D, Silva MR. Qualidade de mudas clonais de Eucalyptus urophylla $\times$ E. grandis em função do substrato. Agriambi 2012; 16(3): 297-302. 10.1590/S1415-43662012000300010

Trindade C, Rezende JLP, Jacovine LAG, Sartório ML. Ferramentas da qualidade: aplicação na atividade florestal. 2nd ed. Viçosa: UFV; 2007.

Vettorazzi CA, Ferraz SFB. Silvicultura de precisão: uma nova perspectiva para o gerenciamento de atividades florestais. In: Borém A, Giudice MP, Queiróz DM, Mantovani EC, Ferreira LR, Valle FXR, Gomide RL, editors. Agricultura de precisão. Viçosa: UFV; 2000. p. 65-75.

Wilcken CF, Lima ACV, Dias TKR, Masson MV, Ferreira Filho PJ, Dal Pogetto MHFA. Guia prático de manejo de plantações de eucalipto. Botucatu: FEPAF; 2008. 